\title{
Muuseumid ja nende mõju praktilises muuseumitöös
}

Pille Runnel

Agnes Aljas

ERMi aastaraamatu käesolevasse numbrisse on koondatud kolm Eesti muuseumide tegevust analüüsivat uurimust. Nende väärtus seisneb ühelt poolt muuseumide praktilise tegevuse toetamises ja tegevussuundade üle polemiseerimises ning teisalt dialoogi astumises muuseumiuuringute valdkonnas aktuaalsete aruteludega. Uurimusi ühendab kaks suuremat teemaringi: külastajate ja muuseumikogukondade teenistuses olemine ning muuseumide ühiskondlik mõju ja sellega seotud rollid. Muuseumide olulisust 
ja tähenduslikkust vaadatakse suuresti läbi nende võime suhelda kogukondade ja auditooriumidega. Kes on aga need inimesed, millised on nende vajadused, kui sarnased ja erinevad need on? Kultuuril ja kultuuripärandil on suur potentsiaal - hoides pärandit ja kasutades seda nii tuleviku loomiseks kui selleks, et toetada inimeste heaolu siin ja praegu.

Hoolimata sellest, et muuseumide auditooriumikesksusest palju räägitakse, väljendub inimkeskne perspektiiv muuseumide arengukavades või ka hindamismudelites valdavalt ikkagi vaid külastajanumbrite või teenusega rahulolu taseme jälgimises. Mitte vaid Eestis, aga ka Euroopas ja maailmas pööratakse samas tähelepanu sellele, kuidas muuseumide ühiskondlikku olulisust hinnata ja kuidas mõõta kultuuriinstitutsioonide mõju. Püütakse leida mõõdikuid ja mudeleid, mis annaksid võimaluse institutsioone omavahel vettpidavalt võrrelda. Samas on sellisel perspektiivil omad piirangud: see vaatenurk ei lähtu arusaamast, et iga muuseum on 
unikaalne - nii selles, kuidas muuseumitöö protsessid kokku on pandud kui ka selles, kes on üldse nende auditooriumid - ja viimaks, millised on just selle asutuse töötajate unikaalsete teadmiste, oskuste ja maailmavaate kombineerimisest sündivad ainulaadsed võimalused. Iga muuseum peaks oskama uurida ka seda, mis on oluline just selle muuseumiga seotud inimestele ja kogukondadele, ja mida muuseumil on sellest lähtuvalt neile pakkuda.

Artiklite üheks ühendavaks teljeks on ka muuseumitöö muutumine ja rollide mitmekülgsus, sealhulgas muuseumis töötamiseks vajalikud uued oskused. Juba 1979. aastal kritiseeris Prantsuse museoloog ja ICOMi president Hugues de Varine muuseumikuraatoreid, kes on tegutsenud aastaid oma asutuses, ümbritsetuna kogudest ja pärandist, teadmata midagi selles linnas ja riigis elavatest inimestest (de Varine, tsiteeritud de la Rocha Mille 2011: 197 kaudu). Kriitikat toetas ka 1980. aastate uus museoloogia, mis pidas muuseume liialt elitaarseteks, kolonialistlikeks, vaid kogudele 
ja kogumismeetoditele keskenduvateks (Vergo 1989). 1990. aastatel jõudsid Lääne-Euroopas kuraatorite kõrvale muuseumitöö ülesandeid täitma ka ürituste korraldajad, projektijuhid ja administraatorid, kelle osakaal on näituste ja muuseumide muutumisega järjest kasvanud.

\section{Tänapäevaseid muuseume ei} määratleta enam nende kogude, vaid suhete järgi külastajate ning muuseumide vahel. Kureerimisest ja muuseumitööst on saanud tugev koos kogukonnaga töötamise ja kaasamise vahend (Kirshenblatt-

Gimblett 1998: 138), millest räägivad kolm siinset artiklit. Praktikas tähendab see, et näituse, kogude, haridusprogrammi või teadustegevuse kureerimine on muutunud horisontaalsemaks. Selle osaks on koostöökohtade otsimine turundusvaldkonna ja administratiivse logistika, akadeemiliste teadlaste, disainerite, muuseumipedagoogide ning paljude teiste muuseumitöö valdkondade vahel. Muuseumitöötaja on muutunud eksperdist vahendajaks, kelle tegevust määratlevad vastuolulised 
suundumused. On teada, et muuseumide edukus on seotud uuenduslikkuse, pidevalt lisanduvate tegevuste ja teemadega. Samas vajab suurem osa muuseumis toimuvast pikaajalist planeerimist ja läbimõtlemist (Scott 2006).

Kuidas asetuvad nende teemade ning väljakutsete konteksti siinsed artiklid? ERMi väljaannetes on järjepidevalt ilmunud käsitlusi külastajaja auditooriumiuuringutest. Krista Lepiku, Reet Mägi ja Pille PruulmannVengerfeldti artikkel jätkab selle valdkonna uurimistööd, analüüsides auditooriumide rolli Tartu Ülikooli loodusmuuseumi uue püsiekspositsiooni loomisel. Kui varasemad artiklid on käsitlenud pigem institutsiooni kui terviku tasandit ja tegelenud kaasamisviiside otsimisega muuseumitöös (või mõnel juhul ka nende muuseumitöösse lõimimisega), on käesoleva uurimuse fookus auditooriumide ja kaasamisviiside kitsamatel aspektidel: millised lähenemised kuraatoritöös domineerivad, kuidas need tekivad ja mis neid suunavad. Uurimuse keskmes on 
kaasamine, mõistes seda tegevustena, mis vastavad muuseumi eesmärkidele, toovad auditooriumides esile teatud reaktsioone või kutsuvad eri viisidel osalema muuseumi tegevustes (Lotina ja Lepik 2015: 127; Lotina 2016: 35). Kuidas on aga auditooriumid kaasatud näituste produktsioonietappi, kus osaleb vaid näitusemeeskond eesotsas kuraatoritega?

Hanna-Liis Kondi uurimus vaatab küll ühe muuseumitegevuse arendamise esimesi samme, kuid tema töö on informatiivne ülevaade sellest, milline näeb välja kultuurija haridustegevuste ristamine muuseumitöös. Kultuuri ja hariduse valdkondade seos on pika ajalooga, kuid on praeguste ühiskondlike väljakutsete valguses - ja lootuses leida viise nendega toimetulekuks - taas strateegilise tähtsusega. Nii määratleb Euroopa kultuurivaldkonna uus tegevuskava (New European Agenda For Culture 2020) nende valdkondade ühendamist lähiaastate peaaegu kõige olulisema küsimusena. Tuntud Euroopa kultuurimõjude valdkonna konsultant, majandusteaduse professor Pierluigi Sacco 
(2021) on öelnud koguni, et kultuuri- ja haridusvaldkonna vaheliste innovatsioonija ristamisstrateegiate väljatöötamine võib olla äärmiselt võimas platvorm inimeste käitumuslikeks muutusteks, kuna see suurendab suutlikkust tulla toime eesootavate suurte sotsiaalsete katsumustega, nagu ühtekuuluvus, vaimne tervis ja innovatsioonile orienteeritud käitumisviiside arendamine igas vanuses inimeste puhul. Euroopa „Agenda for Culture“ eesmärk nr 2 (New European Agenda For Culture 2020) on kultuuripõhise loovuse toetamine hariduses ja innovatsioonis, sest see loob töökohti ja toetab (majandus)kasvu. Tegevuskava üks strateegilisi eesmärke on „edendada kunste, kultuuri ja loovat mõtlemist hariduse ja õpingute kõigil astmetel, sealhulgas elukestvas õppes“.

Kuidas vastab sellisele suurejoonelisele agendale praktiline muuseumitöö? HannaLiis Kondi artiklis vaadeldakse, kuidas Eesti kunstimuuseumides ühendatakse kiusuennetus ja kunsti vahendamine nii haridusprogrammide kui osaliselt ka 
näituste ülesehituses. See on osa muuseumide tegevuskavast aktiivsel panustamisel inimeste heaollu. Analüüsitav kiusuennetusprogramm oli välja töötatud üldhariduskoolide õpilastele ja artikkel uurib, kuidas õnnestus ühendada kiusuennetus kunsti vahendamisega. Tulemused on paljulubavad, sest valdkondade süntees tundides näis toimivat: korraga oli võimalik käsitleda kunsti olemust, sotsiaalseid oskusi ja hoiakuid, ja näis, et need eesmärgid pigem toetasid üksteist. Kiusuennetustegevus tuleks muuseumis tugevamalt siduda muude strateegiliste eesmärkidega, et sellised algatused ei jääks vaid katsetuseks.

Kolmanda artikli eesmärgiks on arutleda muuseumide ühiskondliku mõju üle, sidudes selle Eesti Vabaõhumuuseumi maaarhitektuuri keskuse arenguplaanidega. Fookus on seega keerukal kooslusel, kus muuseumiinstitutsiooni vastutusala asub väljaspool organisatsiooni arhitektuuripärandi tutvustamine ja uurimine põimub tihedalt pärandihalduse küsimustega. Rasmus Kask otsib artiklis muuseumide ühiskondlike mõjude määratlemise suundi, analüüsides viimase 15 aasta erialakirjanduses 
esile toodud muuseumide ja ühiskonna suhtemudeleid. Tema analüüsis joonistub välja kolm peamist mudelit või kategooriat: avalik väärtus, ühiskondlik mõju ja ühiskondlik muutus. Need mudelid eristuvad üksteisest teoreetiliste aluste, sihtrühma määratluse, tegevussuundade ning mõjuindikaatorite kirjelduse poolest.

Tulemustele tuginedes analüüsib autor Eesti Vabaõhumuuseumi maaarhitektuuri keskuse varasemaid arengukavu ja arutleb selle üle, kuidas suunata uue arengukava loomisprotsessi nii, et keskuse arengukava toetaks senisest suurema ühiskondliku mõju saavutamist. Kase käsitlus viitabki sellele, et lisaks otseste mõõdikute leidmisele, mis võiksid aidata kindlaks teha näiteks pärandihoidmise alase teavitustöö efektiivsust, võib olla vajalik läbi mõelda ka väliskeskkonnas toimuvad muudatused: äkki annab keskuse tegevuse tulemuslikkusest kõige paremini märku hoopis kultuuripärand ise ehk maa-arhitektuuriobjektide seisund? Kuidas aga sel juhul mõista, milline roll on siin olnud keskusel, kuna arhitektuuripärandi 


\section{seisundit mõjutavad regionaalareng, elanikkonna kasvamine ja kahanemine, ja ka ühiskondlik kestlikkuspoliitika laiemalt.}

\section{Kirjandus}

A New European Agenda For Culture. 2020. https://ec.europa.eu/culture/document/new-european-agenda-culture-swd2018-267-final.

Viimati külastatud 27.04.2021.

de la Rocha Mille, Raymond. 2011. Museums without walls: The museology of Georges Henri Riviere. Unpublished Doctoral thesis, City University London. https://openaccess.city. ac.uk/id/eprint/2154/1/de_la_Rocha_Mille\%2C_ Raymond.pdf.

Kirshenblatt-Gimblett, Barbara. 1998. Destination Culture: Tourism, Museums, and Heritage. Berkeley/London: University of California Press.

Lotina, Linda. 2016. Conceptualizing Engagement Modes: Understanding Museum-Audience Relationships in Latvian Museums. [Doktoritöö.] Tartu: Tartu Ülikooli Kirjastus.

Lotina, Linda, Krista Lepik. 2015. Exploring Engagement Repertoires in Social Media: the Museum Perspective. - Journal of Ethnology and Folkloristics 9 (1): 123-142.
New European Agenda for Culture. 2020. https://ec.europa.eu/culture/document/ new-european-agenda-cultureswd2018-267-final.

Viimati külastatud 13.04.2021

Sacco, Pierluigi. 2021. Culture-education crossovers. G2o Multi-Stakeholder Webinar „Human Capital. The Driver of Culture-Led Regeneration“" 13. aprillil 2021. https://media.beniculturali. it/mibac/files/boards/be78e33bc8caoc99bff7oaa174035096/PDF/G20\%20Culture\%20 Webinar\%203\%20Human\%2ocapital.pdf. Viimati külastatud 27.04.2021

Scott, C. 2006. Museums: Impact and value. Cultural Trends 15 (1): 45-75.

Vergo, P. 1989. The New Museology. London: Reaktion Books. 